Article

\title{
Self-Organized Nanoparticles of Random and Block Copolymers of Sodium 2-(Acrylamido)-2-methyl-1- propanesulfonate and Sodium 11-(Acrylamido)undecanoate as Safe and Effective Zika Virus Inhibitors
}

\author{
Pawel Botwina ${ }^{1,2}{ }^{\oplus}$, Magdalena Obłoza ${ }^{3}$, Maria Zatorska-Płachta ${ }^{3}$, Kamil Kamiński $^{3}{ }^{\oplus}$, Masanobu Mizusaki $^{4}{ }^{(}$, \\ Shin-Ichi Yusa ${ }^{4}$ D , Krzysztof Szczubiałka ${ }^{3}$ (D), Krzysztof Pyrc ${ }^{2, *(D)}$ and Maria Nowakowska ${ }^{3, *(D)}$ \\ check for \\ 1 Microbiology Department, Faculty of Biochemistry, Biophysics and Biotechnology, Jagiellonian University, \\ 30-387 Krakow, Poland; pawel.botwina@doctoral.uj.edu.pl \\ 2 Virogenetics Laboratory of Virology, Malopolska Centre of Biotechnology, Jagiellonian University, \\ 30-387 Krakow, Poland \\ 3 Department of Physical Chemistry, Faculty of Chemistry, Jagiellonian University, 30-387 Krakow, Poland; \\ m.obloza@uj.edu.pl (M.O.); maria.zatorska@doctoral.uj.edu.pl (M.Z.-P.); kaminski@chemia.uj.edu.pl (K.K.); \\ k.szczubialka@uj.edu.pl (K.S.) \\ 4 Department of Applied Chemistry, Graduate School of Engineering, University of Hyogo, 2167 Shosha, \\ Himeji 671-2280, Japan; mizusaki.masanobu@sharp.co.jp (M.M.); yusa@eng.u-hyogo.ac.jp (S.-I.Y.) \\ * Correspondence: k.a.pyrc@uj.edu.pl (K.P.); nowakows@chemia.uj.edu.pl (M.N.)
}

updates

Citation: Botwina, P.; Obłoza, M.; Zatorska-Płachta, M.; Kamiński, K.; Mizusaki, M.; Yusa, S.-I.; Szczubiałka, K.; Pyrc, K.; Nowakowska, M. SelfOrganized Nanoparticles of Random and Block Copolymers of Sodium 2-(Acrylamido)-2-methyl-1propanesulfonate and Sodium 11(Acrylamido)undecanoate as Safe and Effective Zika Virus Inhibitors. Pharmaceutics 2022, 14, 309. https://doi.org/10.3390/ pharmaceutics14020309

Academic Editor: Haibing Zhou

Received: 2 December 2021

Accepted: 24 January 2022

Published: 27 January 2022

Publisher's Note: MDPI stays neutral with regard to jurisdictional claims in published maps and institutional affiliations.

Copyright: (C) 2022 by the authors. Licensee MDPI, Basel, Switzerland. This article is an open access article distributed under the terms and conditions of the Creative Commons Attribution (CC BY) license (https:// creativecommons.org/licenses/by/ $4.0 /)$.

\begin{abstract}
A series of anionic homopolymers, poly(sodium 2-(acrylamido)-2-methyl-1-propanesulfonate) (PAMPS) and amphiphilic copolymers of AMPS and sodium 11-(acrylamido)undecanoate (AaU), both block $\left(\right.$ PAMPS $\left._{75}-\mathrm{b}-\mathrm{PAaU} \mathrm{U}_{\mathrm{n}}\right)$, and random $\left(\mathrm{P}\left(\mathrm{AMPS}_{\mathrm{m}}-\mathrm{CO}-\mathrm{AaU} \mathrm{U}_{\mathrm{n}}\right)\right)$, were synthesized and their antiviral activity against Zika virus (ZIKV) was evaluated. Interestingly, while the homopolymers showed limited antiviral activity, the copolymers are very efficient antivirals. This observation was explained considering that under the conditions relevant to the biological experiments ( $\mathrm{pH} 7.4$ PBS buffer) the macromolecules of these copolymers exist as negatively charged (zeta potential about $-25 \mathrm{mV}$ ) nanoparticles (4-12 $\mathrm{nm}$ ) due to their self-organization. They inhibit the ZIKV replication cycle by binding to the cell surface and thereby blocking virus attachment to host cells. Considering good solubility in aqueous media, low toxicity, and high selectivity index (SI) of the PAMPS-b-PAaU copolymers, they can be considered promising agents against ZIKV infections.
\end{abstract}

Keywords: Zika virus; sodium 2-(acrylamido)-2-methyl-1-propanesulfonate; sodium 11-(acrylamido) undecanoate; amphiphilic copolymers

\section{Introduction}

Zika virus (ZIKV) is a positively stranded RNA virus that belongs to the Flaviviridae family. The family encompasses a number of viruses, including dengue virus (DENV), West Nile virus (WNV), and yellow fever virus (YFV) [1]. Zika virus was first isolated in the forests of Uganda from a sample collected from rhesus monkey in 1947 [2]. The transmission cycle of ZIKV used to be primarily sylvatic and was limited to primates and mosquitos of Aedes species [3]. The first case of Zika virus-associated disease in humans was recorded in 1954 during an outbreak in Nigeria [4], and until 2007, ZIKV was associated with sporadic infections in humans.

In 2007, the first outbreak of ZIKV was reported on Yap islands and the Federal States of Micronesia. Up to $73 \%$ of the population of the islands above the age of three were infected with ZIKV, and $\sim 20 \%$ of these exhibited clinical symptoms [5]. The next ZIKV outbreak in humans was identified on French Polynesia in 2013-2014, with an estimated 28,000 cases $(11.5 \%$ of the Polynesian population) [6,7]. The virus reached the Western 
Hemisphere in Brazil in 2013 and rapidly spread throughout Central and Southern America, including the United States [8-10]. More than 800,000 documented and suspected human cases of ZIKV were reported in the Americas from 2015 to 2018, along with potentially millions of undiagnosed infections [11]. Most infections remain asymptomatic or manifest with mild symptoms, including fever, rash, arthralgia, or conjunctivitis. However, ZIKV is neurotropic, and it can cause severe neurological complications, including the GuillainBarré syndrome (GBS) [12] and congenital Zika syndrome (CZS) [13] in fetuses. The absolute risk of adverse birth outcomes (i.e., miscarriage, stillbirth, premature birth, and CZS) has been estimated to range between 7 and 46\% [8,14-17]. Currently, there are no specific antiviral drugs or vaccines available to treat or prevent ZIKV infections.

The strategies using polymeric macromolecules as antivirals have been widely studied. Initially, natural polymers were used as backbones (e.g., polysaccharides), but soon the research expanded to also utilize synthetic polymers [18-21]. High efficacy, ease of modification and low toxicity compared to small molecule drugs make them attractive candidates for antiviral drugs. Moreover, polymers are often effective in inhibiting more than one type of virus, which can be useful in countering diseases with diverse etiological factors, e.g., the common cold. Antiviral polymers typically block virus attachment or entry into cells by creating a protective macromolecular barrier on the cell surface or interacting with the virions themselves [22-24].

Moreover, polymers exhibit a phenomenon called "polyvalency" when multiple repeating units of the polymer can bind to multiple complementary cell receptors or viral proteins simultaneously $[19,25]$. As multiple individual ligand-receptor interactions act synergistically, polyvalent interactions are typically much stronger than monovalent binding. That can be affected by selecting the polymeric structures adopting spherical conformation in aqueous media and exposing the functional binding groups. Such a strategy was applied in the current work. A series of amphiphilic copolymers of sodium 2-acrylamido-2-methylpropanesulfonate (AMPS) and sodium 11-acrylamido undecanoate $(\mathrm{AaU})$, both block $\left(\mathrm{PAMPS}_{75}-\mathrm{b}-\mathrm{PAaU} \mathrm{U}_{\mathrm{n}}\right)$ and random $\left(\mathrm{P}\left(\mathrm{AMPS}_{50}-\mathrm{CO}-\mathrm{AaU}_{50}\right)\right.$, undergoing self-organization in aqueous media with the formation of spherical, highly charged coreshell micelles were synthesized and tested for their ability to hamper ZIKV replication cycle in vitro [26]. Their antiviral activity was compared with poly(2-acrylamido-2-methyl1-propanesulfonic acid) (PAMPS) polyanions, including one with the same number of charged sulfonic units. It was observed that while PAMPS-PAaU copolymers (block and random) exhibited strong antiviral efficacy against ZIKV, the ionic homopolymers PAMPS showed relatively limited activity. The copolymers efficiently inhibit the ZIKV-caused cytopathic effect (CPE) and virus yield in cell culture supernatants at very low concentrations $\left(\mathrm{IC}_{50}<1 \mu \mathrm{g} / \mathrm{mL}\right)$. Additionally, the tested copolymers show low toxicity with a $\mathrm{CC}_{50}$ above $2000 \mu \mathrm{g} / \mathrm{mL}$. The mechanistic studies indicated that the polymers studied blocked virus attachment to the host cells, preventing its entry. That process is expected to be driven by electrostatic interactions between the negatively charged sulfonate units present in polymers studied and positively charged glycoproteins located at the cell surface. Interestingly, however, the mechanism of antiZIKV activity of copolymers PAMPS and PAaUn differs considerably from that identified by us for poly(sodium 4-styrenesulfonate) (PSSNa). We demonstrated recently that poly(sodium 4-styrenesulfonate) (PSSNa) inhibits ZIKV replication in vitro both in animal and human cells mostly by binding to the ZIKV particle, thus blocking its attachment to the host cells [24]. The process is efficient when the polymer of high molecular weight is applied. The comparison of the antiviral efficiency of PAMPS homopolymer and copolymers having the same numbers of PAMPS units indicates that this is the self-organization of the polymer chains that plays an essential role in that process. This is because PAMPS homopolymers, being strong polyelectrolytes, adopt rather extended conformation in water (with hydrodynamic radiuses, $R_{\mathrm{h}}$, and zeta potentials, $\zeta, 2-4 \mathrm{~nm}$ and $-20 \mathrm{mV}$, respectively), while PAMPS-PAaU copolymers in aqueous media form negatively charged nanosized micellar particles with $R_{\mathrm{h}}$ and $\zeta$ of 5-12 nm and $-25 \mathrm{mV}$, respectively. They can compete with virus particle interactions with cell 
receptors. Such mechanism of action was recently demonstrated for nanoballs of tridecafullerenes appended with up to 360 1,2-mannobioside units. These particles inhibited entry of ZIKV and Dengue viruses (DENV) to the host cell by blocking the intercellular adhesion molecule-3-grabbing nonintegrin (DC-SIGN) [27,28]. While they are effective as antivirals, the synthesis is demanding. The macromolecular systems proposed in the current paper can be easily prepared using well-mastered reversible addition-fragmentation chain transfer (RAFT) radical polymerization. Their structure, composition, molecular mass and resulting biological properties can be adjusted accordingly. Thus, the homopolymers or copolymers best suited to counteract viral infection can be designed and synthesized.

\section{Materials and Methods}

PAMPS homopolymers and diblock copolymers (Figure 1) composed of poly(sodium 2-acrylamido-2-methyl-1-propanesulfonate) (PAMPS) and poly(sodium 11-acrylamido undecanoate) (PAaU) were synthesized via reversible addition-fragmentation chain transfer (RAFT) radical polymerization following the procedure described earlier [26].
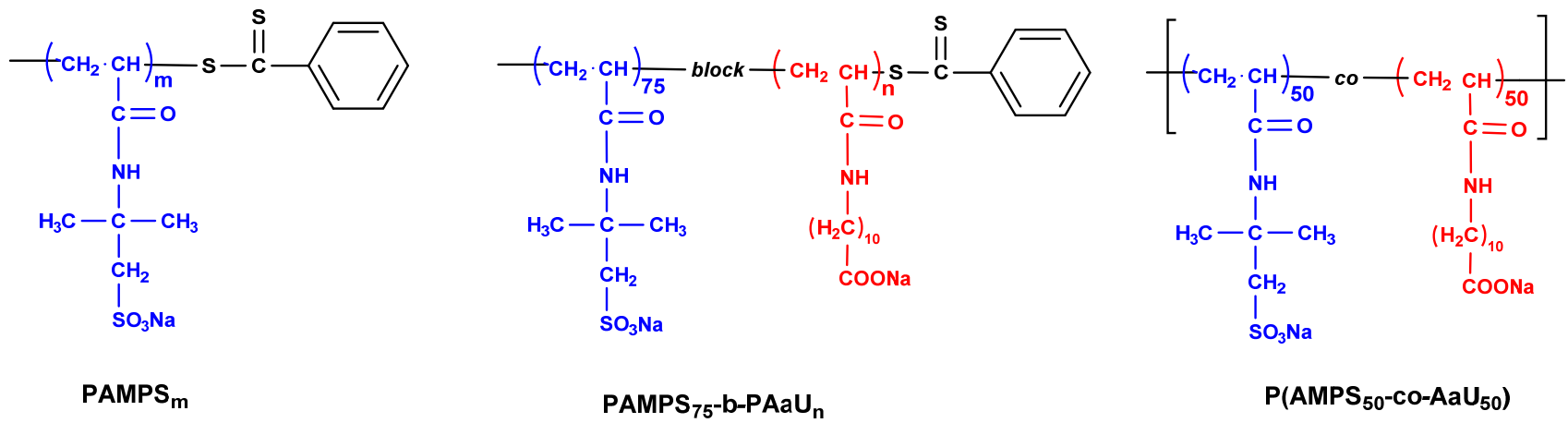

Figure 1. Chemical structures of PAMPS homopolymer, diblock PAMPS $_{75}-\mathrm{b}-\mathrm{PAaU}_{\mathrm{n}}$ copolymers and random $\mathrm{P}\left(\mathrm{AMPS}_{50}-\mathrm{CO}-\mathrm{AaU}_{50}\right)$ copolymer.

A typical synthesis of PAMPS $_{75}-\mathrm{b}-\mathrm{PAaU}_{\mathrm{n}}$ is given in Supplementary Materials. Random copolymer $\mathrm{P}\left(\mathrm{AMPS}_{50}-\mathrm{CO}-\mathrm{AaU}_{50}\right)$ was prepared via free radical polymerization using the procedure described earlier (for details see Supplementary Materials) [29]. The synthesis and characterization of fluorescently labeled copolymer $\mathrm{PAMPS}_{75}-\mathrm{b}-\mathrm{PAaU}_{28}-\mathrm{b}-\mathrm{F}$ is described in Supplementary Materials.

Size Exclusive Chromatography (SEC) analysis was performed at $40{ }^{\circ} \mathrm{C}$ with a reflective index (RI) detector equipped with a Shodex 7.0 $\mu \mathrm{m}$ bead size GF-7F HQ column (exclusion limit 107) using an appropriate eluent at a flow rate of $0.6 \mathrm{~mL} / \mathrm{min}$. Mn, weight-average molecular weight $(\mathrm{Mw})$, and $\mathrm{Mw} / \mathrm{Mn}$ of the polymer were calibrated with standard poly(sodium styrenesulfonate) samples of 11 different molecular weights ranging from $1.37 \times 10^{3}$ to $2.61 \times 10^{6}$.

UV-Vis spectra were collected at RT in $1 \mathrm{~cm}$ quartz cuvettes using single beam photodiode array with Hewlett-Packard 8452A spectrophotometer (Palo Alto, CA, USA) with a resolution of $2 \mathrm{~nm}$ in the range of $190-820 \mathrm{~nm}$.

The ${ }^{1} \mathrm{H}$ NMR spectra were obtained with a Bruker DRX-500 spectrometer (Billerica, MA, USA) operating at $500 \mathrm{MHz}$ in D2O and Bruker Avance II $600 \mathrm{MHz}$ in DMSO. Chemical shifts were determined by using 3-(trimethylsilyl)propionic-2,2,3,3-d4 acid as an internal reference. The $1 \mathrm{H}$ NMR spin-spin relaxation times (T2) were determined by the Carr-Purcell-Meiboom-Gill (CPMG) method [30]. A $90^{\circ}$ pulse of $13.85 \mu$ s was calibrated and used for the measurement. Peak intensities at 12 different numbers of $180^{\circ}$ pulse were measured.

Nano ZS instrument (Malvern Instrument, Worcestershire, UK) was applied for zeta potential (ZP) and dynamic light scattering (DLS) measurements. The light scattering angle was equal to $173^{\circ}$. ZP measurements were performed using the laser Doppler velocimetry technique. Folded capillary cells were utilized in all measurements. 


\subsection{Cells and Virus}

Vero cell line (Cercopithecus aethiops kidney epithelial, ATCC CCL-81) (ATCC, Manassas, VA, USA) was cultured in Dulbecco-modified Eagle's medium (DMEM, high glucose, Life Technologies, Warszawa, Poland) with addition of $10 \%$ heat-inactivated fetal bovine serum (FBS, Life Technologies, Warszawa, Poland), penicillin $(100 \mu \mathrm{g} / \mathrm{mL})$, and streptomycin $(100 \mu \mathrm{g} / \mathrm{mL})$. Cells were cultured in an atmosphere supplemented with $5 \% \mathrm{CO}_{2}$ at $37^{\circ} \mathrm{C}$.

Zika virus (ZIKV, strain H/PF/2013) was acquired from BEI Resources, Manassas, VA, USA. Virus stocks were prepared by infecting confluent Vero cells with the ZIKV at $400 \mathrm{TCID}_{50} / \mathrm{mL}$. After four days of infection, cells underwent three freeze-thaw cycles. Then, supernatants were collected, aliquoted and stored at $-80{ }^{\circ} \mathrm{C}$. The infectivity of generated stock was measured using Reed and Muench titration method [31]. Mockinfected control was prepared in parallel using non-infected cells.

\subsection{XTT Assay}

In order to measure cell viability, commercially available kit (XTT Cell Viability Assay kit, Biological Industries, Cromwell, CT, USA) was used. Cells were incubated with tested compounds at for 3 days at $37{ }^{\circ} \mathrm{C}$. Then, medium was discarded, and $100 \mu \mathrm{L}$ of fresh medium was overlaid on cells. Next, $50 \mu \mathrm{L}$ of activated 2,3-bis-(2-methoxy-4-nitro-5sulfenyl)-(2H)-tetrazolium-5-carboxanilide (XTT) solution was added to each well and plates were incubated at $37^{\circ} \mathrm{C}$ for $2 \mathrm{~h}$. The absorbance was evaluated using Spectra MAX 250 spectrophotometer $(\lambda=490 \mathrm{~nm}$; Molecular Devices, San Jose, CA, USA). Data are shown as the ratio of signal from the tested sample and the control sample (solvent-treated cells) $\times 100 \%$.

\subsection{RNA Isolation and RT-qPCR}

Viral RNA isolation was carried out using a commercially available kit (Viral DNA/RNA Isolation Kit, A\&A Biotechnology, Gdańsk, Poland) according to manufacturer's protocol. For copy number quantification, isolated RNA was subjected to reverse transcription (R.T.) and quantitative real-time PCR (RT-qPCR) reaction using the GoTaq ${ }^{\circledR}$ Probe 1-Step RT-qPCR System kit (Promega, Madison, WI, USA). The supernatants were diluted 1000-fold before isolation to prevent charged polymers from adversely affecting the isolation process [32].

The RT-qPCR reaction was conducted in $10 \mu \mathrm{L}$, containing $1 \times$ GoScript $^{\mathrm{TM}} \mathrm{RT}$ Mix for 1-Step RT-qPCR, $1 \times$ GoTaq $^{\circledR}$ Probe qPCR Master Mix with dUTP, specific probe labeled with 6-carboxyfluorescein (FAM) and 6-carboxytetramethylrhodamine (TAMRA) (5'FAM-CGGCATACAGCATCAGGTGCATAGGAG- TAMRA-3', $300 \mathrm{nM})$, and starters (5'TTGGTCATGATACTGCTGATTGC-3' and 5'-CCTTCCACAAAGTCCCTATTGC-3' $450 \mathrm{nM}$ ). The reaction was carried out in CFX96 Touch ${ }^{\mathrm{TM}}$ Real-197 Time PCR Detection System (Bio-Rad, Warszawa, Poland). The RT-qPCR program consisted of the following steps: $15 \mathrm{~min}$ at $45^{\circ} \mathrm{C}$ (reverse transcription), $2 \mathrm{~min}$ at $95^{\circ} \mathrm{C}$, then 40 cycles of $15 \mathrm{~s}$ at $95^{\circ} \mathrm{C}$ and $30 \mathrm{~s}$ at $60^{\circ} \mathrm{C}$. To enable the quantification of the number of vRNA copies in a sample, standards were subjected to RT-qPCR. Briefly, PCR product was amplified and cloned into pTZ57R/T (Thermo Fisher Scientific, Warszawa, Poland) plasmid using the InsTAclone PCR cloning kit (Thermo Fisher Scientific, Warszawa, Poland). Obtained vector was amplified and linearized using HindIII restriction enzyme. Linear product was purified with the GeneJET PCR purification kit (Thermo Fisher Scientific, Warszawa, Poland) according to the manufacturer's instructions. The concentration was assessed using a NanoDrop ${ }^{\mathrm{TM}}$ 2000 spectrophotometer (Thermo Fisher Scientific, Warszawa, Poland). The number of DNA copies was assessed and samples were serially diluted and used as an input for real-time PCR.

\subsection{Virus Inhibition Assay}

Vero cells were infected with $100 \mu \mathrm{L}$ ZIKV $\left(2000 \mathrm{TCID}_{50} / \mathrm{mL}\right)$ in the presence of different concentrations of studied polymers. At $2 \mathrm{~h}$ post-infection, cells were washed 
thrice with PBS, and then were incubated with polymers for 3 days at $37^{\circ} \mathrm{C}$. Supernatants were collected, and the number of ZIKV RNA copies was assessed using RT-qPCR.

\subsection{In Vitro Mechanism of Action}

To determine at which step the PAMPS-PAaU copolymers hampered the ZIKV replication, a set of assays was performed as described before [24] with some modifications. In brief:

Assay I, "virus inactivation assay", verified the direct inactivation of the virus by the tested compounds. Virus stock was incubated with copolymers $(25 \mu \mathrm{g} / \mathrm{mL})$ for $1 \mathrm{~h}$ at room temperature with mixing. Then, mixtures were diluted with medium to dilute virus stock to the final concentration of $10,000 \mathrm{TCID}_{50} / \mathrm{mL}$ and copolymers below their active concentration $(<1 \mu \mathrm{g} / \mathrm{mL})$. Cells were overlaid with $100 \mu \mathrm{L}$ of prepared samples and incubated for $2 \mathrm{~h}$ at $37^{\circ} \mathrm{C}$. Cells were washed three time with PBS, and fresh media was applied. Infection was carried out for $12 \mathrm{~h}$ at $37^{\circ} \mathrm{C}$, and supernatants were subjected to RT-qPCR analyses.

Assay II, "cell protection assay", examined if compounds interact with the host cell and protect it from the viral infection. In order to test that, Vero cells were incubated with $100 \mu \mathrm{L}$ of copolymers $(25 \mu \mathrm{g} / \mathrm{mL})$ in growth media for $1 \mathrm{~h}$ at $37^{\circ} \mathrm{C}$. Next, cells were washed with PBS three times and later infected with ZIKV at 10,000 TCID $50 / \mathrm{mL}$ in $100 \mu \mathrm{L}$ for $2 \mathrm{~h}$. Next, cells were washed thrice with PBS to remove any residual virus. Then, fresh media was added and infection was carried out for $12 \mathrm{~h}$ at $37^{\circ} \mathrm{C}$. After incubation, supernatants were collected for RT-qPCR analyses.

Assay III, "virus entry assay", allowed examining if tested polymers blocked the early steps of virus infection. Cells were overlaid with $100 \mu \mathrm{L}$ of copolymer-virus mixture $\left(10,000 \mathrm{TCID}_{50} / \mathrm{mL}, 25 \mu \mathrm{g} / \mathrm{mL}\right)$ and infected for $2 \mathrm{~h}$ at $4{ }^{\circ} \mathrm{C}$ to allow the virus attachment, but not internalization into the host cells. Next, cells were washed with PBS three times and $100 \mu \mathrm{L}$ of fresh media was added. Cells were incubated for $12 \mathrm{~h}$ at $37^{\circ} \mathrm{C}$, and supernatants were collected for RT-qPCR analyses.

Assay IV, "virus replication, assembly, and egress assay", examined whether compounds inhibited ZIKV replication after virus entry. To test that, cells were infected with ZIKV with the dose of $10,000 \mathrm{TCID}_{50} / \mathrm{mL}$ in $100 \mu \mathrm{L}$ and incubated for $2 \mathrm{~h}$ at $37^{\circ} \mathrm{C}$. After infection, cells were rinsed thrice with PBS to remove any residual virus. Then, $100 \mu \mathrm{L}$ of tested copolymers in the growth medium was added at concentration of $25 \mu \mathrm{g} / \mathrm{mL}$. Infection was carried out for $12 \mathrm{~h}$ at $37^{\circ} \mathrm{C}$, and supernatants were subjected to RT-qPCR analyses.

\subsection{Fate of Nanoparticles after Interaction with Vero Cells}

To answer the question regarding the fate of PAMPS-PAaU copolymer nanoparticles after incubation with Vero cells, two types of experiments were carried out. In the first one Vero cells were seeded on coverslips in 6-well plates and were incubated with $1000 \mu \mathrm{L}$ of $\mathrm{PAMPS}_{75}-b-\mathrm{PAaU}_{28}-b-\mathrm{F}(25 \mu \mathrm{g} / \mathrm{mL})$ for $1 \mathrm{~h}$ at $37{ }^{\circ} \mathrm{C}$. Next, the medium was refreshed and after $0,3,6$ and 12 h cells were fixed with $4 \%$ formaldehyde. Cells were washed thrice with PBS and nuclear DNA was stained using DAPI $(0.1 \mu \mathrm{g} / \mathrm{mL}$, Sigma-Aldrich, Poznan, Poland) for $20 \mathrm{~min}$ at room temperature. Cells were thoroughly washed with PBS and coverslips were mounted on glass slides and sealed for confocal imaging.

In the second type of experiment, Vero cells were seeded on coverslips in 6-well plates and were incubated with $3000 \mu \mathrm{L}$ of $\mathrm{PAMPS}_{75}-b-\mathrm{PAaU} 8_{28}-b-\mathrm{F}(25 \mu \mathrm{g} / \mathrm{mL})$ for $1 \mathrm{~h}$ at $37^{\circ} \mathrm{C}$. The medium was refreshed, and Vero cells were cultured for $0,1,12$ and $24 \mathrm{~h}$. Then, cells were washed twice with PBS and $1 \mathrm{~mL}$ of methanol was added. An amount of $100 \mu \mathrm{L}$ of each methanol extract was diluted and fluorescence spectra was collected using HITACHI F-7100 spectrofluorometer (excitation wavelength $\lambda_{\mathrm{ex}}=450 \mathrm{~nm}$ ). 


\subsection{Fluorescence Microscopy}

To evaluate the interaction of polymeric nanoparticles with the cells, Vero cells were seeded on coverslips in 6-well plates and were incubated with $1000 \mu \mathrm{L}$ of PAMPS $75-b$ $\mathrm{PAaU}_{28}-b-\mathrm{F}(50 \mu \mathrm{g} / \mathrm{mL})$ for $1 \mathrm{~h}$ at $37^{\circ} \mathrm{C}$. Cells were fixed using $4 \%$ formaldehyde, permeabilized with $0.1 \%$ Triton X-100 and washed with PBS thrice. Cells were immunostained with phalloidin conjugated with Alexa Fluor 647 (0.2 U/mL, Invitrogen, Warsaw, Poland) for $2 \mathrm{~h}$. Next, cells were thoroughly washed with PBS and nuclear DNA was stained using DAPI $(0.1 \mu \mathrm{g} / \mathrm{mL}$, Sigma-Aldrich, Poznan, Poland) for $20 \mathrm{~min}$ at room temperature. Cells were washed with PBS, and coverslips with immunostained cells were mounted and sealed on glass slides. Images were acquired with an A1-Si Nikon (Tokyo, Japan) confocal laser scanning system coupled with Nikon inverted microscope Ti-E using a Plan Apo $100 \times / 1.4$ Oil DIC objective. Three-dimensional fluorescence images were generated using NIS-Elements AR 3.2 software (Nikon Europe BV, Amsterdam, The Netherlands).

The experiment was carried out to monitor the interaction of ZIKV with cells in the presence or absence of polymers. Vero cells were seeded on coverslips mounted in 12-well plates (TPP, Trasadingen, Switzerland) to achieve $90 \%$ confluency. Then, cells were infected or mock-infected with $100 \mu \mathrm{L}$ ZIKV $\left(2000 \mathrm{TCID}_{50} / \mathrm{mL}\right)$ in the presence or absence of different concentrations of studied polymers for $48 \mathrm{~h}$.

To study if polymer hampers ZIKV attachment to host cells, Vero cells were seeded on coverslips mounted in 12-well plates (TPP, Trasadingen, Switzerland) to achieve 90\% confluency. Cell were pre-cooled to $4{ }^{\circ} \mathrm{C}$ and incubated with a mixture of virus stock and $50 \mu \mathrm{g} / \mathrm{mL} \mathrm{PAMPS}_{75}-\mathrm{b}-\mathrm{PAaU}_{39}$ in medium containing 0,5 or $10 \%(250 \mu \mathrm{L})$ final concentration of FBS for $1 \mathrm{~h}$ at $4{ }^{\circ} \mathrm{C}$. After incubation, cells were immediately fixed and immunostained.

Cells were then fixed using $4 \%$ formaldehyde, permeabilized with $0.1 \%$ Triton X-100, and non-specific binding sites were blocked using $5 \%$ bovine serum albumin (BSA; Bioshop, Burlington, ON, Canada) in PBS for $2 \mathrm{~h}$. Immunostaining was conducted using rabbit anti-ZIKV envelope antibody (GeneTex, Irvine, CA, USA) at concentration of $1 \mu \mathrm{g} / \mathrm{mL}$ for $2 \mathrm{~h}$. Cells were washed thrice with PBS and incubated with $2.5 \mu \mathrm{g} / \mathrm{mL}$ of Atto 488 goat anti-rabbit secondary antibody (Sigma-Aldrich, Poznan, Poland) along with phalloidin conjugated with Alexa Fluor $647(0.2 \mathrm{U} / \mathrm{mL}$, Invitrogen, Warsaw, Poland $)$ for $1 \mathrm{~h}$. Next, cells were washed with PBS and nuclear DNA was stained using DAPI $(0.1 \mu \mathrm{g} / \mathrm{mL}$, Sigma-Aldrich, Poznan, Poland) for $20 \mathrm{~min}$ at room temperature. Cells washed with PBS, and coverslips with cells were mounted on glass slides in ProLong Diamond Antifade Mountant medium (Life Technologies, Eugene, OR, USA) and sealed. Fluorescent images were acquired using EVOS imaging system (Life Technologies, Carlsbad, CA, USA) and processed using ImageJ (version 1.52b) Fiji software (Madison, WI, USA) [33].

\subsection{Statistics}

The experiments were carried out in at least three replicates. The data are shown as means \pm standard deviations (S.D.). The $50 \%$ inhibitory concentration $\left(\mathrm{IC}_{50}\right)$ and $50 \%$ cytotoxic $\left(\mathrm{CC}_{50}\right)$ values were assessed using the Graph Pad Prism 8.0. The selectivity index (SI) was calculated according to the formula $\mathrm{SI}=\mathrm{CC}_{50} / \mathrm{IC}_{50}$.

The statistical significance of the data presented in the manuscript was assessed with non-parametric Kruskal-Wallis test. $p$ values below 0.05 were considered significant.

The $\log$ removal value $(\mathrm{LRV})$ was calculated according to the formula $L R V=\log \left(\mathrm{C}_{\mathrm{i}} / \mathrm{C}_{0}\right)$, where $C_{i}$ is the number of viral RNA copies per milliliter in the sample from the culture treated with a given polymer and $C_{0}$ is the number of viral RNA copies per milliliter in the control sample (untreated cells).

\section{Results}

\subsection{Polymers}

Homopolymers PAMPS $\mathrm{m}\left(\mathrm{m}=40,75\right.$ and 170) and a series of diblock PAMPS $_{75}$-b$\mathrm{PAaU}_{\mathrm{n}}$ copolymers $(n=3,12,28$, and 39 , respectively) were synthesized via RAFT polymer- 
ization. The random copolymer $\mathrm{P}\left(\mathrm{AMPS}_{50}-\mathrm{CO}-\mathrm{AaU}_{50}\right)$ was obtained in free radical polymerization. The polymer compositions were confirmed by ${ }^{1} \mathrm{H}$ NMR (Supplementary Materials, Figures S1-S3). The structures of these polymers are presented in Figure 1 and their characteristics are shown in Table 1.

Table 1. Molecular weights and compositions of the polymers.

\begin{tabular}{|c|c|c|c|c|c|}
\hline Polymer & $\begin{array}{c}M_{\mathrm{n}}{ }^{\mathrm{a}} \\
\left(\times 10^{4}\right)\end{array}$ & $\underset{\left(\times 10^{4}\right)}{\bigoplus^{a}}$ & $M_{\mathrm{w}} / M_{\mathrm{n}}{ }^{\mathrm{a}}$ & D.P. (AMPS) ${ }^{b}$ & D.P. (AaU) ${ }^{c}$ \\
\hline PAMPS $_{40}$ & 0.94 & 1.21 & 1.28 & 40 & 0 \\
\hline PAMPS $_{75}$ & 1.72 & 2.18 & 1.26 & 75 & 0 \\
\hline PAMPS $_{170}$ & 3.93 & 4.65 & 1.18 & 170 & 0 \\
\hline PAMPS $_{75}-\mathrm{b}-\mathrm{PAaU}_{3}$ & 1.85 & 2.61 & 1.41 & 75 & 3 \\
\hline PAMPS $_{75}-\mathrm{b}-\mathrm{PAaU}_{12}$ & 3.20 & 4.53 & 1.42 & 75 & 12 \\
\hline PAMPS $_{75}-\mathrm{b}-\mathrm{PAaU}_{28}$ & 5.05 & 6.72 & 1.33 & 75 & 28 \\
\hline PAMPS $_{75}-\mathrm{b}-\mathrm{PAaU}_{39}$ & 7.63 & 9.36 & 1.23 & 75 & 39 \\
\hline $\mathrm{P}\left(\mathrm{AMPS}_{50}-\mathrm{co}-\mathrm{AaU}_{50}\right)$ & $4.38^{\mathrm{d}}$ & $9.90^{\mathrm{d}}$ & $2.26^{\mathrm{d}}$ & $50^{\mathrm{e}}$ & $50^{\mathrm{e}}$ \\
\hline
\end{tabular}

${ }^{a} M_{n}$, number average molecular mass, $M_{\mathrm{w}}$, weight average molecular mass, $\emptyset$, dispersity index were determined by SEC in $\mathrm{H}_{2} \mathrm{O} / \mathrm{CH}_{3} \mathrm{CN}(80 / 20, v / v) 0.1 \mathrm{M} \mathrm{NaNO}_{3}$ solution calibrated with poly(sodium styrenesulfonate) standards. ${ }^{b}$ D.P., degree of polymerization of AMPS determined by SEC in $\mathrm{H}_{2} \mathrm{O} / \mathrm{CH}_{3} \mathrm{CN}(80 / 20, v / v) 0.1 \mathrm{M}$ $\mathrm{NaNO}_{3}$ solution calibrated with poly(sodium styrenesulfonate) standards. ${ }^{c}$ D.P., degree of polymerization of AaU determined by ${ }^{1} \mathrm{H}$ NMR in $\mathrm{D}_{2} \mathrm{O}$. ${ }^{\mathrm{d}}$ Determined by SEC using a mixed solvent of water and DMF $(50 / 50, v / v)$ containing $50 \mathrm{mM} \mathrm{LiBr}$ as the eluent. ${ }^{\mathrm{m}} \% \mathrm{~mol}$, determined from ${ }^{1} \mathrm{H} \mathrm{NMR}$ in $\mathrm{D}_{2} \mathrm{O}$ at $95{ }^{\circ} \mathrm{C}$.

All the polymers studied are well-soluble in water; however, due to their amphiphilic nature, they self-assemble in aqueous media with the formation of the core-shell micelles. The process is dependent on a $\mathrm{pH}$ of a solution and can be monitored by the analysis of the motion of polymer chains. ${ }^{1} \mathrm{H}$ NMR spin-spin relaxation time $\left(T_{2}\right)$ was measured as a function of $\mathrm{pH}$. Figure $2 \mathrm{~A}$ shows $T_{2}$ at $1.25 \mathrm{ppm}$, attributed to the pendant methylene protons in the PAaU block as a function of $\mathrm{pH}$. At acidic conditions, $T_{2}$ decreased due to the formation of a hydrophobic core of polymer micelles which restricted motions of the PAaU block.

These obtained data were verified using the dynamic light scattering (DLS) measurements of the dependence of hydrodynamic radius $\left(R_{\mathrm{h}}\right)$ of macromolecules on $\mathrm{pH}$ (Figure 2B). The analysis of data presented in Figure 2A,B demonstrated that at acidic $\mathrm{pH}$ (pH 3), the polymers formed interpolymer micelles comprising PAaU core with PAMPS shells. When $\mathrm{pH}$ increased ( $\mathrm{pH} 8$ ), the polymers formed intrapolymer (unimer) micelles, i.e., each micelle was composed of a single polymer chain. The radius of intrapolymer micelles at $\mathrm{pH}=7.4$ was 8-11 $\mathrm{nm}$ (see Table S1) and reached a minimum value of about 5-7 nm for $\mathrm{pH} 8$-9. Further increase in $\mathrm{pH}$ leads to stronger repulsive electrostatic forces between the pendant sulfonate ionic groups. At $\mathrm{pH} 12$, the micelles completely dissociated, and polymeric chains expanded. The behavior of random $\mathrm{P}\left(\mathrm{AMPS}_{50}-\mathrm{CO}_{-} \mathrm{AaU}_{50}\right)$ was, however, quite different. This polymer formed intrapolymer micelles even at acidic $\mathrm{pH}$. With increasing $\mathrm{pH}$, starting at about $\mathrm{pH} 5$, the micelles began to uncoil, and the polymer chains adopted more and more extended conformation.

The values of $R_{\mathrm{h}}$ and zeta potential of PAMPS-b-PAaU micelles under the conditions relevant to the biological experiments ( $\mathrm{pH} 7.4 \mathrm{PBS}$ buffer, $37^{\circ} \mathrm{C}$ ) are presented in the table below (Figure 2C).

The results of the measurements presented above indicated that when considering the activity of PAMPS-PAaU copolymers in the biological experiments described below ( $\mathrm{pH} 7.4$ ), one should take into account that the macromolecules exist as negatively charged nanosized unimolecular micelles/nanoparticles with hydrodynamic radiuses being in the range 4-12 $\mathrm{nm}$ and zeta potentials around $-25 \mathrm{mV}$ (Figures 2A-C, S4 and S5, Table S1). High values of zeta potential of the polymeric micelles provide stability of their nanodispersions in aqueous media. The comparison of the values of the surface area of the polymeric nanoparticles, calculated based on the assumption that they are ideally spherical, suggests 
that exposure/accessibility of the ionic sulfonate groups is expected to increase with the growing length of nonionic blocks which form the core of these micellar structures.
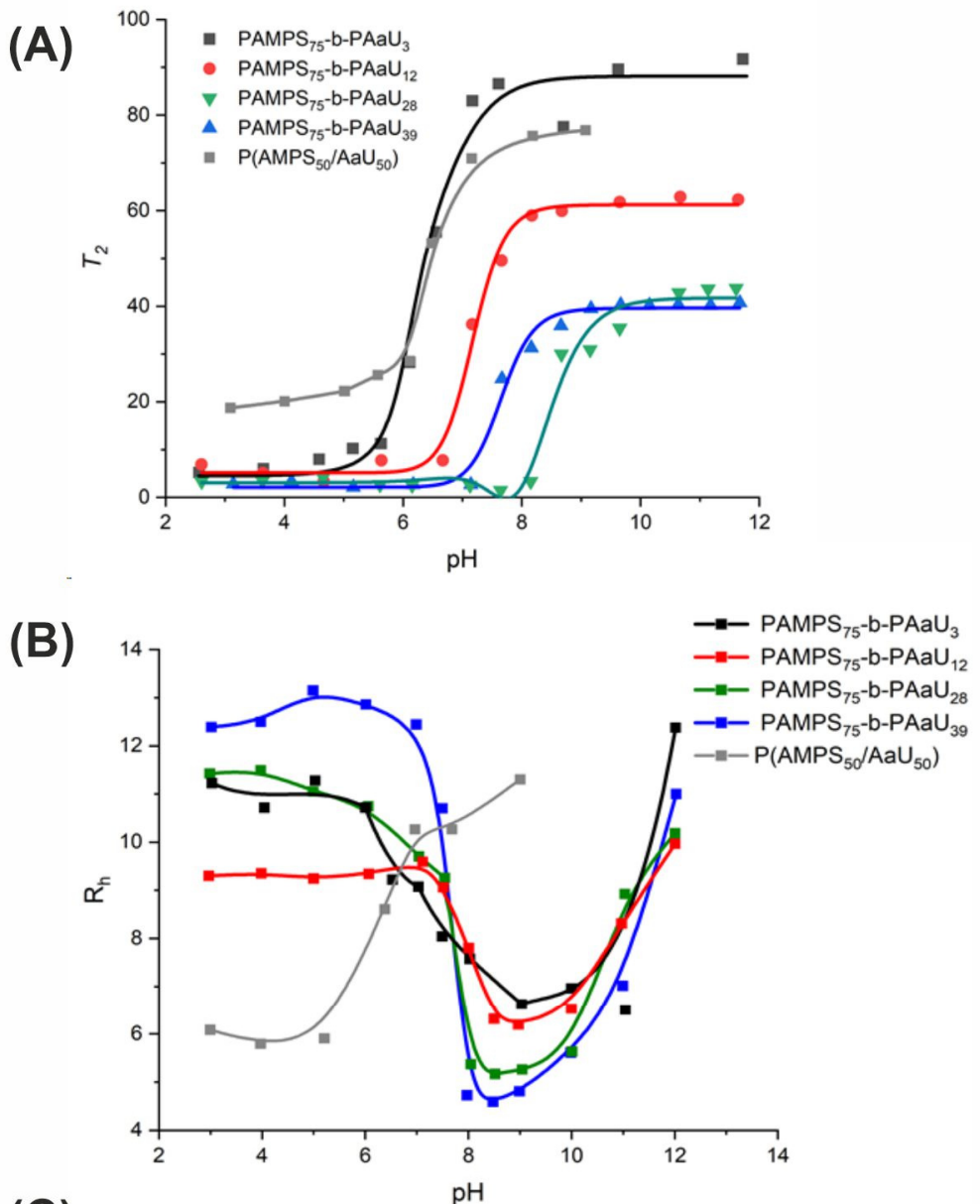

(C)

\begin{tabular}{|c|c|c|c|c|c|}
\hline & $\begin{array}{c}\text { PAMPS }_{75-b-} \\
\text { PAaU }_{3}\end{array}$ & $\begin{array}{l}\text { PAMPS }_{75-b-} \\
\text { PAaU }_{12}\end{array}$ & $\begin{array}{c}\text { PAMPS }_{75-b-} \\
\text { PAaU }_{28}\end{array}$ & $\begin{array}{l}\text { PAMPS }_{75-b-} \\
\text { PAaU }_{39}\end{array}$ & $\begin{array}{c}\text { P(AMPS } \\
\text { AaU }_{50} \text {-co- }\end{array}$ \\
\hline$R_{\mathrm{h}}(\mathrm{nm})$ & $4.0 \pm 0.1$ & $4.8 \pm 0.1$ & $4.9 \pm 0.5$ & $11.6 \pm 0.5$ & $8.0 \pm 2.6$ \\
\hline $\begin{array}{l}\text { Surface area of } \\
\text { the sphere }\left(\mathrm{nm}^{2}\right)\end{array}$ & 200.96 & 289.38 & 301.57 & 1690.07 & 803.84 \\
\hline PDI & $0.65 \pm 0.12$ & $0.94 \pm 0.11$ & $0.53 \pm 0.06$ & $0.32 \pm 0.06$ & $0.38 \pm 0.07$ \\
\hline $\begin{array}{c}\text { Zeta potential } \\
(\mathrm{mV})\end{array}$ & $-22.9 \pm 1.3$ & $-24.3 \pm 2.2$ & $-24.8 \pm 2.5$ & $-25.7 \pm 0.8$ & $-24.2 \pm 1.2$ \\
\hline
\end{tabular}

Figure 2. PAMPS-b-PAaU block copolymers form interpolymer micelles. Spin-spin relaxation time $\left(T_{2}\right)$ of ${ }^{1} \mathrm{H}$ NMR signal at 1.25 ppm for PAMPS $_{75}-\mathrm{b}-\mathrm{PAaU}_{3}$ (black line), $\mathrm{PAMPS}_{75}$-b-PAaU 12 (red line), PAMPS $_{75}-\mathrm{b}-\mathrm{PAaU}_{28}$ (green line), $\mathrm{PAMPS}_{75}-\mathrm{b}-\mathrm{PAaU}_{39}$ (blue line) and $\mathrm{P}\left(\mathrm{AMPS}_{50}-\mathrm{co}-\mathrm{AaU}_{50}\right.$ ) (grey line) as a function of $\mathrm{pH}$ in $\mathrm{D}_{2} \mathrm{O}$ containing $0.1 \mathrm{M} \mathrm{NaCl}$ at $C_{\mathrm{p}}=10 \mathrm{~g} / \mathrm{L}(\mathrm{A})$. Hydrodynamic radius $\left(R_{\mathrm{h}}\right)$ for $\mathrm{PAMPS}_{75}-b-\mathrm{PAaU}_{3}$ (black line), $\mathrm{PAMPS}_{75}-b-\mathrm{PAaU}_{12}$ (red line), $\mathrm{PAMPS}_{75}-b-\mathrm{PAaU}_{28}$ (green line), PAMPS $_{75}-b-\mathrm{PAaU}_{39}$ (blue line), and $\mathrm{P}\left(\mathrm{AMPS}_{50}-\mathrm{co}-\mathrm{AaU}_{50}\right.$ ) (grey line) as a function of $\mathrm{pH}$ in $0.1 \mathrm{M}$ $\mathrm{NaCl}$ aqueous solutions at $C_{\mathrm{p}}=10 \mathrm{~g} / \mathrm{L}$ and $25{ }^{\circ} \mathrm{C}(\mathbf{B})$. Values of hydrodynamic radius $\left(R_{\mathrm{h}}\right)$, the surface area of the polymeric spherical nanoparticle, dispersity index $(Ð)$ and zeta potentials for PAMPS-PAaU copolymers $\left(C_{\mathrm{p}}=1 \mathrm{mg} / \mathrm{mL}\right.$ in PBS, $\left.\mathrm{pH}=7.4, \mathrm{~T}=25^{\circ} \mathrm{C}\right)(\mathbf{C})$.

\subsection{Cytotoxicity and Cellular Localization of PAMPS-b-PAaU}

XTT assays were carried out to assess the cytotoxicity of tested copolymers towards cells. Vero cells were incubated with solutions of PAMPS $\mathrm{P}_{\mathrm{m}}$ homopolymers, $\mathrm{PAMPS}_{75^{-}}$ b-PAaU $U_{n}$ diblock copolymers and $\mathrm{P}\left(\mathrm{AMPS}_{50}-\mathrm{CO}-\mathrm{AaU}_{50}\right)$ random copolymer at various concentrations for 3 days (Figure $3 \mathrm{~A}, \mathrm{~B}$ ). Our results indicate low cytotoxicity of PAMPS polymers at concentrations up to $500 \mu \mathrm{g} / \mathrm{mL}$. The introduction of PAaU block or random 
structure of PAMPS-PAaU further lowered the toxicity of studied copolymers, increasing $\mathrm{CC}_{50}>2000 \mu \mathrm{g} / \mathrm{mL}$.
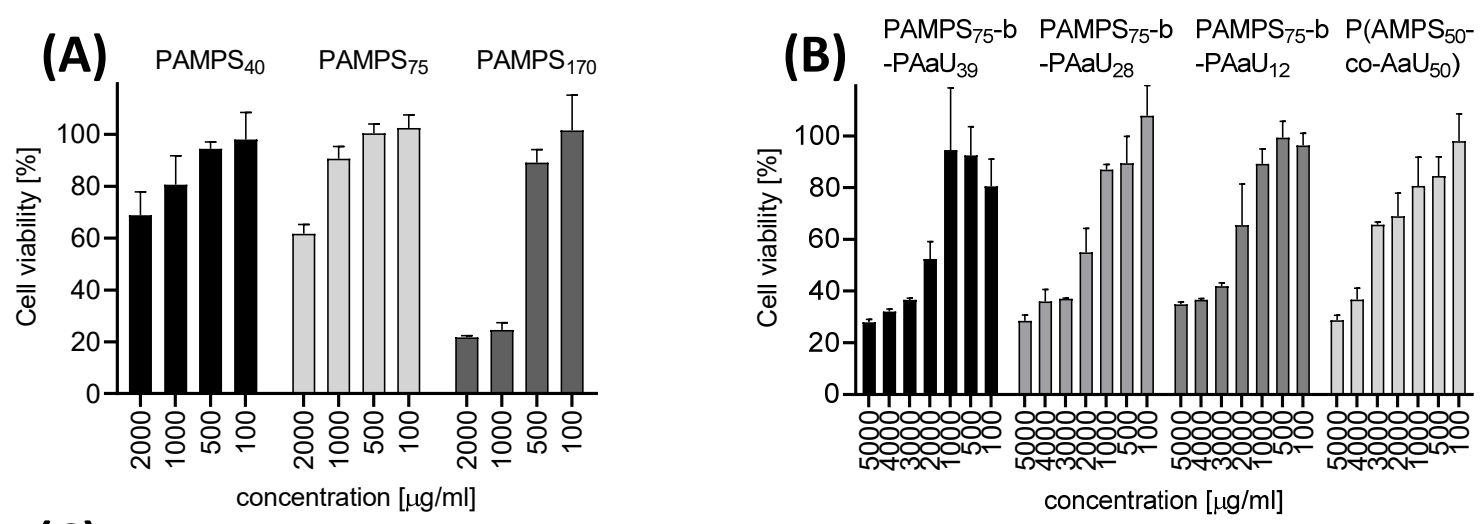

(C)

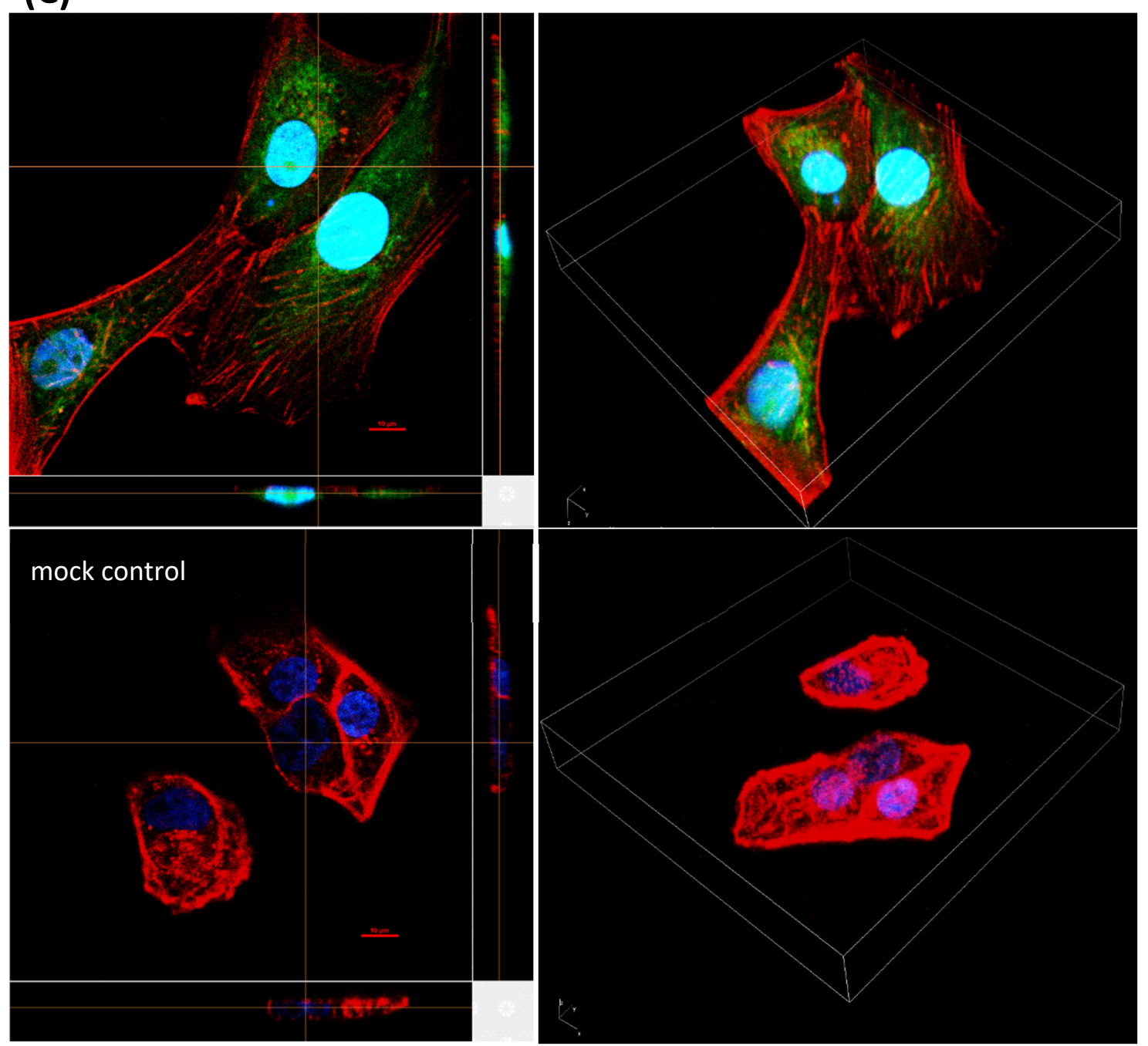

Figure 3. PAMPS-PAaU copolymers are not toxic towards Vero cells. Cytotoxicity of PAMPS homopolymers (A), PAMPS $_{75}-\mathrm{b}-\mathrm{PAaU}$ and $\mathrm{P}\left(\mathrm{AMPS}_{50}-\mathrm{CO}_{\mathrm{AaU}} \mathrm{A}_{50}\right)(\mathbf{B})$ copolymers of various M.W.s at 2000,1000, 500 and $100 \mu \mathrm{g} / \mathrm{mL}$. Results of XTT assay of the tested polymers on Vero cells. All experiments were performed in triplicate. Average values with standard error of the mean (error bars) are presented. (C) Three-dimensional fluorescent images of Vero cells incubated with $50 \mu \mathrm{g} / \mathrm{mL}$ of $\mathrm{PAMPS}_{75}-b-\mathrm{PAaU}_{28}-b$-F for $1 \mathrm{~h}$. Cell nuclei are denoted in blue, actin is denoted in red and fluorescent polymer is green. 
The interaction of studied copolymers with Vero cells was followed by observation of fluorescence laser scanning confocal images of the cells incubated with fluorescently labeled PAMPS $_{75}-b-\mathrm{PAaU}_{28}-b-\mathrm{F}$ copolymer (Figures 3C and S7-S10). Green fluorescence observed inside the cells indicated that the polymer nanoparticles localized in the cytoplasm shortly after addition. Further observations suggest, however, that they are eliminated from cells, because after $24 \mathrm{~h}$ after incubation only a very weak signal from PAMPS $_{75}-b-\mathrm{PAaU}_{28}-b-\mathrm{F}$ was observed (Figure S10).

\subsection{Antiviral Tests}

To assess the antiviral properties of studied macromolecules, Vero cells were infected with ZIKV in the presence or absence of tested polymers at different concentrations. Obtained data are summarized on Figure 4. PAMPS $\mathrm{m}_{\mathrm{m}}$ polymers showed weak potential to

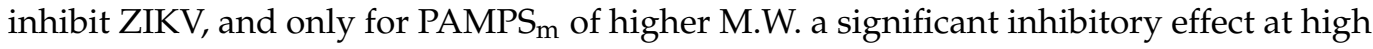
concentrations was noted $(250 \mu \mathrm{g} / \mathrm{mL}$, Figure $4 \mathrm{~A})$.

Surprisingly, adding a block of PAaU to PAMPS increased the inhibitory activity of the tested compounds. Block copolymers reduced the CPE at concentrations of $25 \mu \mathrm{g} / \mathrm{mL}$ or lower, and these observations were supported by the RT-qPCR data (Figures $4 \mathrm{~B}$ and S10). The strongest antiviral effect was shown for the polymers with the longest PAaU chain; however, the differences were slight. $\mathrm{P}\left(\mathrm{AMPS}_{50}-\mathrm{CO}_{-} \mathrm{AaU}_{50}\right)$ showed similar antiviral properties, showing the highest reduction in ZIKV copy number at the highest concentrations, however, less inhibition at lower concentrations, resulting in a higher $\mathrm{IC}_{50}$ dose compared to PAMPS $_{75}$-b-PAaUn $($ Figure $4 \mathrm{C}$ ). In contrast, PAMPS 75 -b-PAaU 3 did not inhibit ZIKV replication in the tested concentration range (data not shown). This confirms that inhibitory properties of $\mathrm{PAMPS}_{75}-\mathrm{b}-\mathrm{PAaU} \mathrm{U}_{\mathrm{n}}$ correlate with the charge of polymer nanoparticles, which depends on the size of the PAaU block. The increase in the size of micelle core increases nanoparticle zeta potential, as more ionic groups are exposed at the particle surface in micelles with larger cores. To test this hypothesis, experiments using a series of PAMPS $75-\mathrm{b}-$ $\mathrm{PAaU}_{\mathrm{n}}$ copolymers with longer PAaU blocks must be carried out. Higher antiviral activity of larger micelles is consistent with the assumption that the inhibitory mechanism involves the multivalent interactions of negatively charged ionic groups of polymers with positively charged glycoproteins located at the cell receptors.

Infectivity analyses of the supernatants from ZIKV samples treated with the tested copolymers confirmed the inhibitory effect (Figure 4D). All copolymers lowered the virus titers by $\sim 2.5$ orders of magnitude at $25 \mu \mathrm{g} / \mathrm{mL}$ in a dose-dependent manner. Fluorescence microscopy images also showed strong inhibition of ZIKV infection. While the majority of control cells showed ZIKV E protein production, only single cells were infected in the samples treated with the copolymers (Figure 4E).

\subsection{Mechanism of Action}

To investigate the mechanism of action for PAMPS-PAaU copolymers, a set of functional assays was carried out (Figure 5A-D). As shown in Figure 5A, the copolymers do not directly inactivate virions. After one hour of incubation with the copolymers and dilution of the copolymers, we observed no inhibition of infection, as was the case with preincubation of cells with compounds (Figure 5B). The results show that inhibition occurred early during the infection, but the polymers do not affect the virus itself (Figure 5C). This suggests that polymers can interfere with the process of virus attachment to the cell by the competition or changing the charge of the binding sites. To confirm these observations, cells were incubated with the virus in the presence or absence of copolymer at $4{ }^{\circ} \mathrm{C}$ to allow virus attachment to the cell surface, but not internalization. After incubation, samples were fixed and visualized by fluorescence microscopy (Figure 5E). An analysis of 10 random images of the control group and cells treated with the copolymer at a concentration of $25 \mu \mathrm{g} / \mathrm{mL}$ was performed. A significant reduction was found in the number of virus particles attached to the cell in the presence of PAMPS $75-\mathrm{b}-\mathrm{PAaU}_{\mathrm{n}}$ copolymers (Figure 5F). To test whether the serum could inactivate the copolymers, an attachment test was performed at different 
FBS concentrations. The results show no dependence of the blocking of ZIKV attachment to cells on the serum concentration. It is worth pointing out that our results also show a weaker inhibition at later steps of the virus replication cycle, especially in the case of $\mathrm{P}\left(\mathrm{AMPS}_{50}-\mathrm{CO}-\mathrm{AaU}_{50}\right)$ (Figure 5D). Therefore, an additional mode of action cannot be excluded, especially in light of the results showing that the copolymers penetrate the cell membrane and enter the cells. In conclusion, these results point out that PAMPS-PAaU copolymers inhibit the ZIKV replication cycle by blocking virus attachment to host cells.

(A)

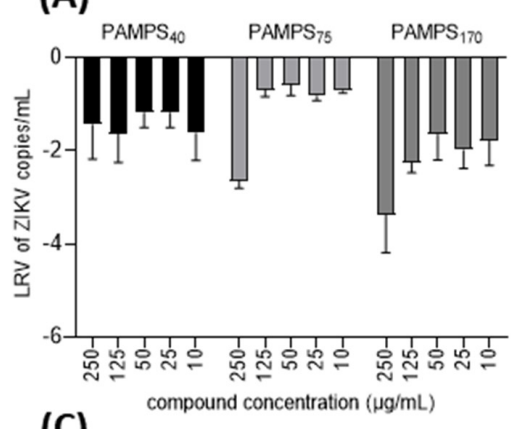

(C)

\begin{tabular}{|c|c|c|c|}
\hline Compound & $\begin{array}{c}\mathrm{IC}_{50} \\
(\mu \mathrm{g} / \mathrm{mL})\end{array}$ & $\begin{array}{c}\mathrm{CC}_{50} \\
(\mu \mathrm{g} / \mathrm{mL})\end{array}$ & $\mathrm{SI}$ \\
\hline $\begin{array}{c}\mathrm{PAMPS}_{75^{-}} \\
\mathrm{PAaU}_{39}\end{array}$ & 0.25 & 2388 & 9552 \\
\hline $\begin{array}{c}\mathrm{PAMPS}_{75^{-}} \\
\mathrm{PAaU}_{28}\end{array}$ & 0.29 & 2444 & 8428 \\
\hline $\begin{array}{c}\mathrm{PAMPS}_{75^{-}} \\
\mathrm{PAaU}_{12}\end{array}$ & 0.26 & 2916 & 11215 \\
\hline $\begin{array}{c}\mathrm{P}\left(\mathrm{AMPS}_{50}-\right. \\
\left.\mathrm{CO}^{-} \mathrm{AaU}_{50}\right)\end{array}$ & 0.81 & 3227 & 3984 \\
\hline
\end{tabular}

(E)

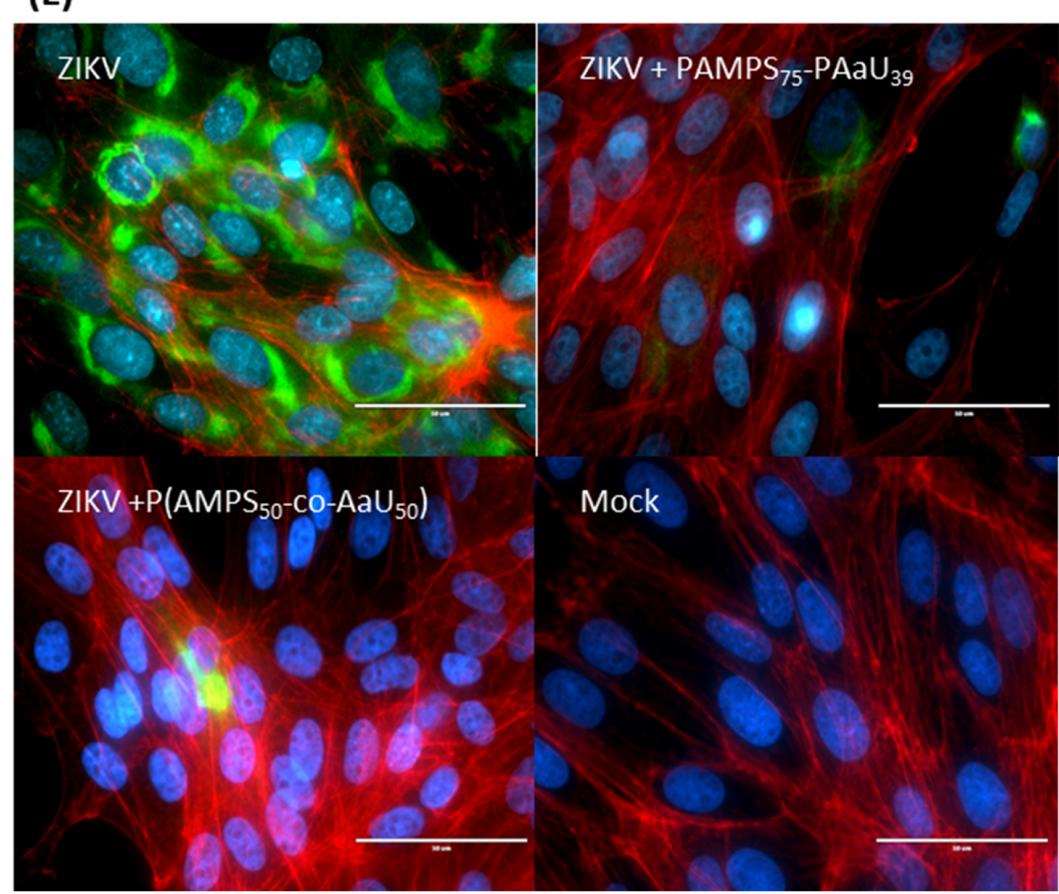

(B) PAMPS $_{75-b}$ PAMPS $_{75-b}$ PAMPS $_{75-b}$ P(AMPS $_{50-}$

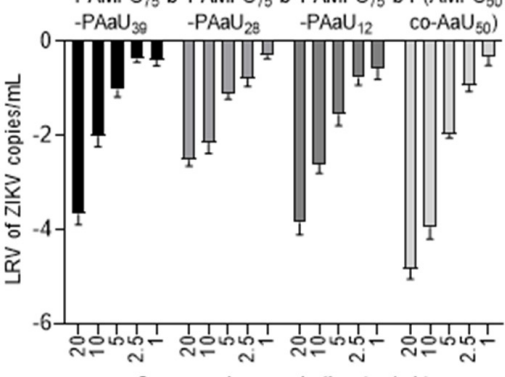

(D)

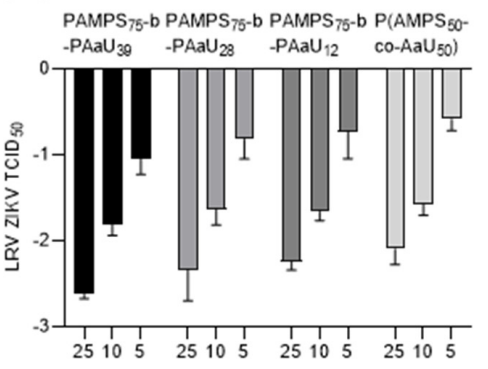

Compound concentration $(\mu \mathrm{g} / \mathrm{mL})$

Figure 4. $\mathrm{PAMPS}_{75}-\mathrm{b}-\mathrm{PAaU}$ n block copolymers are potent inhibitors of Zika infection in vitro. (A) The inhibition of the ZIKV by PAMPS polymers. (B) PAMPS $75-\mathrm{b}-\mathrm{PAaU}_{\mathrm{n}}$ block copolymers and $\mathrm{P} \mathrm{AMPS}_{50^{-}}$ co-AaU $\mathrm{U}_{50}$ ) copolymer at various concentrations in Vero cells. Inhibition of the infection was evaluated by RT-qPCR. Vero cells were infected in the presence of appropriate polymer concentrations for 3 days. Data are shown as logarithmic reduction values (LRV) of ZIKV RNA copy number per milliliter with 
SEM (error bars). (C) $\mathrm{CC}_{50}, \mathrm{IC}_{50}$ and selectivity index (SI) values for PAMPS-PAaU block and random copolymers. (D) Titration results of supernatants of Vero cells infected in the presence or absence of $\mathrm{PAMPS}_{75}-\mathrm{b}-\mathrm{PAaU} \mathrm{U}_{\mathrm{n}}$ block copolymers and $\mathrm{P}\left(\mathrm{AMPS}_{50}-\mathrm{co}-\mathrm{AaU}_{50}\right)$ random copolymer in different concentrations. Data are shown as logarithmic reduction values of supernatant infectivity $\left(\mathrm{TCID}_{50}\right)$ per milliliter of at least three replications. (E) Fluorescence images of cells infected with ZIKV $\left(\operatorname{TCID}_{50}=2000 / \mathrm{mL}\right)$ in the presence or absence of the polymers at $25 \mu \mathrm{g} / \mathrm{mL}$ for $48 \mathrm{~h}$. Cell nuclei are shown in blue, actin is shown in red and ZIKV E protein is denoted in green. Scale bar $=50 \mu \mathrm{m}$.

(A)

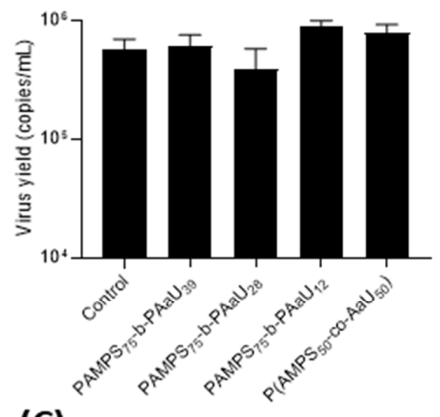

(C)

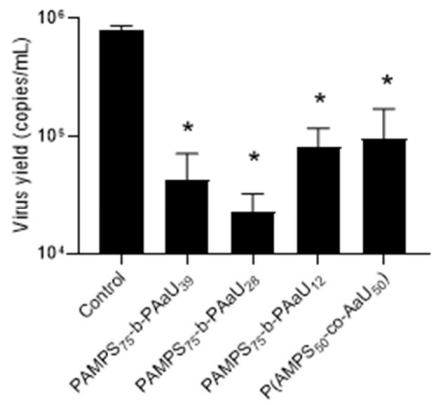

(B)

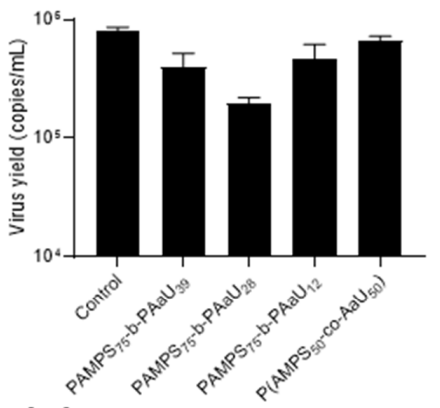

(D)

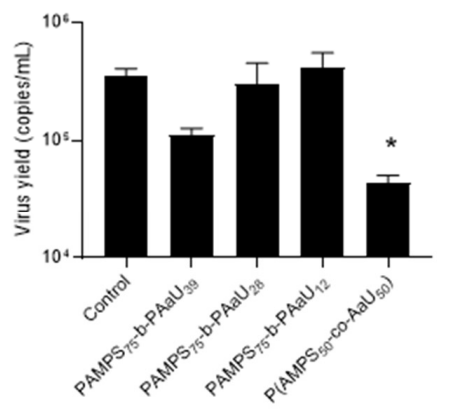

(E)

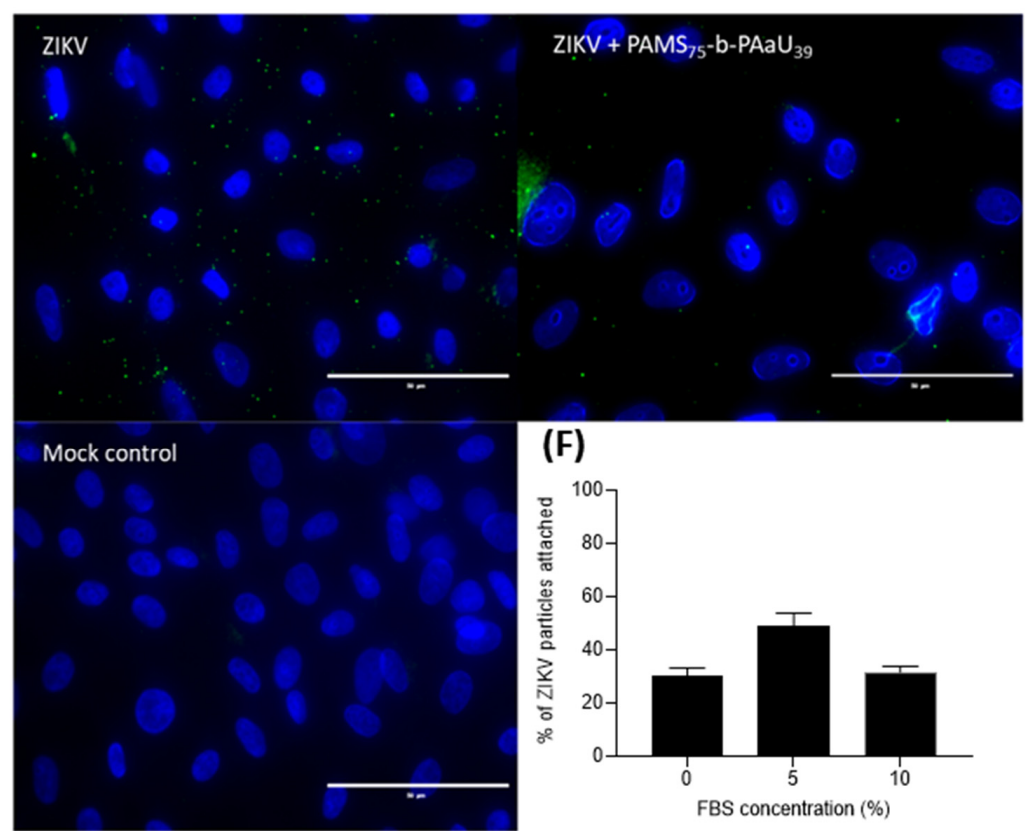

Figure 5. PAMPS $_{75}-\mathrm{b}-\mathrm{PAaU}_{39}$ inhibits the ZIKV replication cycle by blocking virus attachment. Inhibitory activity of copolymers was tested in Vero cells, as described in the Materials and Methods 
section: virus inactivation assay (A); cell protection assay (B); virus entry assay (C); virus replication, assembly, and egress assay (D). RT-qPCR was used to assess the number of viral RNA copies and to evaluate the inhibition of the infection. The experiments were carried out in triplicate. The data are shown as average values with SEM (error bars). ${ }^{*}(p<0.05)$ denotes values that are significantly different from the control. Representative fluorescent images of ZIKV particles on the cell surface (E). Vero cells were incubated with ZIKV in the presence or absence of PAMPS $75-b-P^{-} A_{39}(25 \mu \mathrm{g} / \mathrm{mL})$ at $4{ }^{\circ} \mathrm{C}$. Cell nuclei are denoted in blue, and ZIKV E protein is denoted in green. The number of ZIKV virions attached to the cells (F). The individual counts, including the statistical error of the mean, are shown.

\section{Discussion}

This work demonstrated that PAMPS-PAaU copolymers are efficient Zika virus inhibitors at submicromolar concentrations. The mechanistic studies indicated that they inhibit the ZIKV replication cycle by blocking virus attachment to host cells. The exact molecular mechanism of action remains to be fully understood. Based on the literature and PAMPS-PAaU composition, one can propose the involvement of several possible receptors.

The rapid spread of the ZIKV in 2016 created high demand towards understanding the virus biology. The determination of the molecular mechanisms of early-stage ZIKVhost interaction and virus internalization would help in developing therapeutic strategies. However, the results are still not satisfactory. Research on skin-building cells has shown that human dermal fibroblasts, epidermal keratinocytes, and immature dendritic cells are permissive to ZIKV. Further research showed that ZIKV interacted with various types of non-specific and specific attachment factors. Like other flaviviruses, ZIKV uses heparan sulfate domains as non-specific attachment factors, assisting in virus interaction with primary receptors by retaining viral particles on the cell surface until they start to interact with the entry receptor. DC-SIGN and members of phosphatidylserine kinase family, AXL, Tyro3 and/or TIM-1 were identified as the specific ZIKV cellular attachment factors [34]. The same family of primary ZIKV receptors was proposed for other types of cells involved in virus transmission $[35,36]$. Recent proteomic studies allowed identification of the Neural Cell Adhesion Molecule (NCAM1) as a potential ZIKV receptor in Vero cells and human glioblastoma cells U-251 MG [37]. The findings mentioned above suggest that the attractive electrostatic interactions between negatively charged macromolecules of polymers used in current studies and positively charged domains of glycoproteins serving as the primary ZIKV attachment factors are essential for inhibition of the replication cycle. That is in agreement with earlier findings indicating the antiviral activity of heparin [38] and suramin [33]. The application of heparin as an antiviral agent is limited by its anticoagulant activity. Suramin, an approved antiparasitic drug, decreased the intercellular ZIKV RNA levels in a dose-dependent manner. Using the radioactive S-labeled ZIKV demonstrated that suramin interferes with virus attachment to the host Vero cells [35]. It was postulated that suramin binds to the (glyco)proteins of a ZIKV TIM1 receptor or ZIKV AXL receptor present on host cells, respectively [39]. Considering that in suramin and in the polymers used in our studies sulfonate groups are primarily involved in interaction with glycoproteins on a cell surface, one may assume that the same mechanism of action is involved.

Interestingly, we observed that the conformation of the polymeric chain strongly affects the efficiency of the virus inhibition. The macromolecules of PAMPS $75-b-$ PAaU $_{n}$ block copolymers forming negatively charged nanoparticles are much more efficient than PAMPS $_{75}$ homopolymer, having the same number of AMPS units. That can be explained assuming that these polymeric nanoparticles can compete with virus particles for access to the attachment factor/primary cell receptor, and their size and charge density make it in favor of the polymer in this competition with the virus. As was demonstrated above, PAMPSPAaU nanoparticles can finally enter the Vero cells tested, most likely by pinocytosis [40-42]. Although there is considerable literature on mechanisms of elimination of nanoparticles from the individual cells, more comprehensive studies are necessary to elucidate the exact mechanism. It was observed that nanoparticles could be exocytosed out of the cells, and 
the rate of the process was dependent on the chemistry of nanoparticles, and for a given type of nanoparticles, it was inversely proportional to their surface area [43,44].

Overall, our research shows a strong inhibitory effect of $\mathrm{PAMPS}_{75}-\mathrm{b}-\mathrm{PAaU}_{\mathrm{n}}$ copolymers on Zika virus multiplication in vitro. Copolymers show potential for further research into their antiviral properties. After a mosquito bite, Zika spreads throughout the human body through the blood and lymph vessels. The proposed copolymers could therefore act as intravenous drugs used in people at higher risk who have been diagnosed with Zika virus infection, especially in pregnant women. This is indicated by their advantageous physicochemical properties and high selectivity index (SI).

\section{Conclusions}

A series of anionic PAMPS homopolymers as well as amphiphilic block and random PAMPS-PAaU copolymers were synthesized, and their antiviral activity against Zika virus was demonstrated. The polymers are very well-soluble in water, and they self-assemble in an aqueous solution. Under the conditions relevant to the biological experiments ( $\mathrm{pH} 7.4$ PBS buffer, $25^{\circ} \mathrm{C}$ ) the macromolecules of PAMPS $_{75}-\mathrm{b}-\mathrm{PAaU}_{\mathrm{n}}$ block copolymers exist as negatively charged (zeta potential about $-25 \mathrm{mV}$ ) nanosized micelles $(4-12 \mathrm{~nm}$ ). They inhibit the ZIKV replication cycle by blocking virus attachment to the host cells. The process is highly effective. Considering the extremely low toxicity of the PAMPS-PAaU copolymers and their high SI values, these polymers are promising drug candidates against ZIKV.

Supplementary Materials: The following are available online at https:/ /www.mdpi.com/article/10 $.3390 /$ pharmaceutics14020309/s1, Figure S1: ${ }^{1} \mathrm{H}$ NMR spectrum for $\mathrm{PAMPS}_{75}-\mathrm{b}-\mathrm{PAaU}_{39}$ at $C_{\mathrm{p}}=10 \mathrm{~g} / \mathrm{L}$ in $\mathrm{D}_{2} \mathrm{O}$ at $\mathrm{pH} 10$. The DP of the PAaU block was estimated by comparing the intensity of signals $c$ and $b$. Figure S2: DLS profiles for PAMPS-PAaU copolymers $\left(C_{\mathrm{p}}=1 \mathrm{mg} / \mathrm{mL}\right.$ in PBS, $\left.\mathrm{T}=37^{\circ} \mathrm{C}\right)$. Figure S3: Normalized UV-vis absorption (solid line, in water at $\mathrm{pH} 10$ ) and fluorescence spectra (dotted line, in water, $\lambda_{e x}=420 \mathrm{~nm}$ ) of PAMPS $75-\mathrm{b}-\mathrm{PAaU}_{28}-\mathrm{b}-\mathrm{F}$. Figure S4: 3D Fluorescent images of Vero cells incubated with $25 \mu \mathrm{g} / \mathrm{mL}$ of PAMPS $_{75}-b-\mathrm{PAaU}_{28}-b-\mathrm{F}$ for $1 \mathrm{~h}$ and taken after selected period of time. Cell nuclei are denoted in blue and fluorescent polymer is green. Figure S5: Fluorescent images of Vero cells incubated with $25 \mu \mathrm{g} / \mathrm{mL}$ of PAMPS $_{75}-b-\mathrm{PAaU}_{28}-b-\mathrm{F}$ for $1 \mathrm{~h}$ and taken after selected period of time. Cell nuclei are denoted in blue and fluorescent polymer is green (Experiment 1). Figure S6: Fluorescence spectra of methanol extract of Vero cells incubated with PAMPS $75-b-$ $\mathrm{PAaU}_{28}-b-\mathrm{F}(25 \mu \mathrm{g} / \mathrm{mL})$ for $1 \mathrm{~h}$ and collected after selected period of time (Experiment 2), Table S1: The values of hydrodynamic radius $\left(R_{\mathrm{h}}\right)$ for PAMPS-PAaU copolymers $\left(C_{\mathrm{p}}=10 \mathrm{mg} / \mathrm{mL}\right.$ in $0.1 \mathrm{M}$ $\mathrm{NaCl}, \mathrm{pH} \approx 7.5, \mathrm{~T}=25^{\circ} \mathrm{C}$.

Author Contributions: Conceptualization, S.-I.Y., K.S., M.N. and K.P.; methodology, K.S., M.N. and K.P.; validation, K.S., M.N. and K.P.; investigation, P.B., M.O., M.M., K.K. and M.Z.-P.; resources, M.N.; data curation, P.B.; writing —original draft preparation, P.B., M.O., M.M. and M.N.; writing-review and editing, P.B., M.O., S.-I.Y., K.S., M.N. and K.P.; visualization, P.B. and M.O.; supervision, S.-I.Y., K.S., M.N. and K.P.; project administration, M.N. and K.P.; funding acquisition, M.N. All authors have read and agreed to the published version of the manuscript.

Funding: This work was supported by the National Science Centre, Poland, in the form of Grants No. 2017/27/B/ST5/01108 to M.N. and 2016/21/B/NZ6/01307 to K.P.

Institutional Review Board Statement: Not applicable.

Informed Consent Statement: Not applicable.

Data Availability Statement: Data is contained within the article and in Supplementary Material associated with the article.

Conflicts of Interest: The funders had no role in study design, data collection and analysis, decision to publish, or preparation of the manuscript. The author Maria Zatorska-Płachta is currently an employee of MDPI, however she did not work for the journal Pharmaceutics at the time of submission and publication. The other authors declare no conflict of interest. 


\section{References}

1. Knipe, D.M.; Howley, P. Fields Virology, 6th ed.; Lippincott Williams \& Wilkins (LWW): Philadelphia, PA, USA, $2013 ;$ p. 2664.

2. Dick, G.W.A. Zika Virus (I). Isolations and serological specificity. Trans. R. Soc. Trop. Med. Hyg. 1952, 46, 509-520. [CrossRef]

3. Marchette, N.J.; Garcia, R.; Rudnick, A. Isolation of Zika virus from Aedes aegypti mosquitoes in Malaysia. Am. J. Trop. Med. Hyg. 1969, 18, 411-441. [CrossRef] [PubMed]

4. MacNamara, F.N. Zika virus: A report on three cases of human infection during an epidemic of jaundice in Nigeria. Trans. R. Soc. Trop. Med. Hyg. 1954, 48, 139-145. [CrossRef]

5. Duffy, M.R.; Chen, T.H.; Hancock, W.T.; Powers, A.M.; Kool, J.L.; Lanciotti, R.S.; Pretrick, M.; Marfel, M.; Holzbauer, S.; Dubray, C.; et al. Zika virus outbreak on Yap Island, Federated States of Micronesia. N. Engl. J. Med. 2009, 360, 2536-2543. [CrossRef] [PubMed]

6. Musso, D.; Bossin, H.; Mallet, H.P.; Besnard, M.; Broult, J.; Baudouin, L.; Levi, J.E.; Sabino, E.C.; Ghawche, F.; Lanteri, M.C.; et al. Zika virus in French Polynesia 2013-14: Anatomy of a completed outbreak. Lancet Infect. Dis. 2018, 18, e172-e182. [CrossRef]

7. Besnard, M.; Lastère, S.; Teissier, A.; Cao-Lormeau, V.M.; Musso, D. Evidence of perinatal transmission of zika virus, French Polynesia, December 2013 and February 2014. Eurosurveillance 2014, 19, 20751. [CrossRef]

8. Brasil, P.; Pereira, J.P.; Moreira, M.E.; Nogueira, R.M.R.; Damasceno, L.; Wakimoto, M.; Rabello, R.S.; Valderramos, S.G.; Halai, U.A.; Salles, T.S.; et al. Zika virus infection in pregnant women in Rio de Janeiro. N. Engl. J. Med. 2016, 375, 2321-2334. [CrossRef]

9. Osorio-De-Castro, C.G.S.; Miranda, E.S.; De Freitas, C.M.; De Camargo, K.R.; Cranmer, H.H. The Zika Virus outbreak in Brazil: Knowledge gaps and challenges for risk reduction. Am. J. Public Health 2017, 107, 960-965. [CrossRef]

10. Petersen, E.; Wilson, M.E.; Touch, S.; McCloskey, B.; Mwaba, P.; Bates, M.; Dar, O.; Mattes, F.; Kidd, M.; Ippolito, G.; et al. Rapid Spread of Zika Virus in The Americas-Implications for Public Health Preparedness for Mass Gatherings at the 2016 Brazil Olympic Games. Int. J. Infect. Dis. 2016, 44, 11-15. [CrossRef]

11. PAHO. WHO Zika Cumulative Cases. Available online: https://www.paho.org/hq/index.php?option=com_content\&view= article\&id=12390:zika-cumulative-cases\&Itemid=42090\&lang=en (accessed on 1 December 2021).

12. Hughes, R.A.; Cornblath, D.R. Guillain-Barré syndrome. Lancet 2005, 366, 1653-1666. [CrossRef]

13. Moore, C.A.; Staples, J.E.; Dobyns, W.B.; Pessoa, A.; Ventura, C.V.; Da Fonseca, E.B.; Ribeiro, E.M.; Ventura, L.O.; Neto, N.N.; Arena, J.F.; et al. Characterizing the pattern of anomalies in congenital zika syndrome for pediatric clinicians. JAMA Pediatr. 2017, 171, 288-295. [CrossRef] [PubMed]

14. Honein, M.A.; Dawson, A.L.; Petersen, E.E.; Jones, A.M.; Lee, E.H.; Yazdy, M.M.; Ahmad, N.; Macdonald, J.; Evert, N.; Bingham, A.; et al. Birth defects among fetuses and infants of US women with evidence of possible zika virus infection during pregnancy. J. Am. Med. Assoc. 2017, 317, 59-68. [CrossRef] [PubMed]

15. Wheeler, A.C. Development of infants with congenital zika syndrome: What do we know and what can we expect? Pediatrics 2018, 141, S154-S160. [CrossRef] [PubMed]

16. Adachi, K.; Nielsen-Saines, K. Zika clinical updates: Implications for pediatrics. Curr. Opin. Pediatr. 2018, 30, 105-116. [CrossRef] [PubMed]

17. Parra, B.; Lizarazo, J.; Jiménez-Arango, J.A.; Zea-Vera, A.F.; González-Manrique, G.; Vargas, J.; Angarita, J.A.; Zuñiga, G.; Lopez-Gonzalez, R.; Beltran, C.L.; et al. Guillain-Barré Syndrome Associated with Zika Virus Infection in Colombia. N. Engl. J. Med. 2016, 375, 1513-1523. [CrossRef] [PubMed]

18. Zmonarski, S.Z.; Stojanowski, J.; Zmonarska, J. Polymers with antiviral properties: A brief review. Polym. Med. 2021, 50, 79-82. [CrossRef] [PubMed]

19. Bianculli, R.H.; Mase, J.D.; Schulz, M.D. Antiviral Polymers: Past Approaches and Future Possibilities. Macromol. 2020, 53, 9158-9186. [CrossRef]

20. Li, J.; Yu, F.; Chen, Y.; Oupický, D. Polymeric drugs: Advances in the development of pharmacologically active polymers. J. Control. Release 2015, 219, 369-382. [CrossRef]

21. Pinho, A.C.; Piedade, A.P. Polymeric Coatings with Antimicrobial Activity: A Short Review. Polymers 2020, 12, 2469. [CrossRef]

22. Milewska, A.; Ciejka, J.; Kaminski, K.; Karewicz, A.; Bielska, D.; Zeglen, S.; Karolak, W.; Nowakowska, M.; Potempa, J.; Bosch, B.J.; et al. Novel polymeric inhibitors of HCoV-NL63. Antivir. Res. 2013, 97, 112-121. [CrossRef]

23. Milewska, A.; Chi, Y.; Szczepanski, A.; Barreto-Duran, E.; Dabrowska, A.; Botwina, P.; Obloza, M.; Liu, K.; Liu, D.; Guo, X.; et al. HTCC as a Polymeric Inhibitor of SARS-CoV-2 and MERS-CoV. J. Virol. 2021, 95, e01622-20. [CrossRef] [PubMed]

24. Botwina, P.; Obłoza, M.; Szczepański, A.; Szczubiałka, K.; Nowakowska, M.; Pyrć, K. In Vitro Inhibition of Zika Virus Replication with Poly(Sodium 4-Styrenesulfonate). Viruses 2020, 12, 926. [CrossRef] [PubMed]

25. Barron, B.A.; Edwards, K.; Massare, S.J.; McGovern, M.S.; Williams, D.; Capps, S.J.; Dragon, D.M.; Fitzmorris, C.T.; Graul, E.E.; Insler, M.S.; et al. Predictors of recurrent herpes simplex virus keratitis. Cornea 2001, 20, 123-128.

26. Mizusaki, M.; Shimada, Y.; Morishima, Y.; Yusa, S.-I. pH-Responsive Intra- and Inter-Molecularly Micelle Formation of Anionic Diblock Copolymer in Water. Polymers 2016, 8, 56. [CrossRef] [PubMed]

27. Ramos-Soriano, J.; Reina, J.J.; Illescas, B.M.; de la Cruz, N.; Rodríguez-Pérez, L.; Lasala, F.; Rojo, J.; Delgado, R.; Martín, N. Synthesis of Highly Efficient Multivalent Disaccharide/[60]Fullerene Nanoballs for Emergent Viruses. J. Am. Chem. Soc. 2019, 141, 15403-15412. [CrossRef] [PubMed]

28. Ramos-Soriano, J.; Rojo, J. Glycodendritic structures as DC-SIGN binders to inhibit viral infections. Chem. Commun. 2021, 57, 5111-5126. [CrossRef] [PubMed] 
29. Yusa, S.-I.; Sakakibara, A.; Yamamoto, T.; Morishima, Y. Reversible pH-Induced Formation and Disruption of Unimolecular Micelles of an Amphiphilic Polyelectrolyte. Macromolecules 2002, 35, 5243-5249. [CrossRef]

30. Meiboom, S.; Gill, D. Modified Spin-Echo Method for Measuring Nuclear Relaxation Times. Rev. Sci. Instrum. 1958, $29,688-691$. [CrossRef]

31. Reed, L.J.; Muench, H. A simple method of estimating fifty per cent endpoints. Am. J. Epidemiol. 1938, 27, 493-497. [CrossRef]

32. Ciejka, J.; Botwina, P.; Nowakowska, M.; Szczubiałka, K.; Pyrc, K. Synthetic sulfonated derivatives of poly(allylamine hydrochloride) as inhibitors of human metapneumovirus. PLoS ONE 2019, 14, e0214646. [CrossRef]

33. Schindelin, J.; Arganda-Carreras, I.; Frise, E.; Kaynig, V.; Longair, M.; Pietzsch, T.; Preibisch, S.; Rueden, C.; Saalfeld, S.; Schmid, B.; et al. Fiji: An open-source platform for biological-image analysis. Nat. Methods 2012, 9, 676-682. [CrossRef] [PubMed]

34. Hamel, R.; Dejarnac, O.; Wichit, S.; Ekchariyawat, P.; Neyret, A.; Luplertlop, N.; Perera-Lecoin, M.; Surasombatpattana, P.; Talignani, L.; Thomas, F.; et al. Biology of Zika Virus Infection in Human Skin Cells. J. Virol. 2015, 89, 8880-8896. [CrossRef] [PubMed]

35. Tabata, T.; Petitt, M.; Puerta-Guardo, H.; Michlmayr, D.; Wang, C.; Fang-Hoover, J.; Harris, E.; Pereira, L. Zika Virus Targets Different Primary Human Placental Cells, Suggesting Two Routes for Vertical Transmission. Cell Host Microbe 2016, 20, 155-166. [CrossRef] [PubMed]

36. Meertens, L.; Labeau, A.; Dejarnac, O.; Cipriani, S.; Sinigaglia, L.; Bonnet-Madin, L.; Le Charpentier, T.; Hafirassou, M.L.; Zamborlini, A.; Cao-Lormeau, V.-M.; et al. Axl Mediates ZIKA Virus Entry in Human Glial Cells and Modulates Innate Immune Responses. Cell Rep. 2017, 18, 324-333. [CrossRef] [PubMed]

37. Srivastava, M.; Zhang, Y.; Chen, J.; Sirohi, D.; Miller, A.; Chen, Z.; Lu, H.; Xu, J.; Kuhn, R.J.; Tao, W.A. Chemical proteomics tracks virus entry and uncovers NCAM1 as Zika virus receptor. Nat. Commun. 2020, 11, 389. [CrossRef] [PubMed]

38. Kim, S.Y.; Zhao, J.; Liu, X.; Fraser, K.; Lin, L.; Zhang, X.; Zhang, F.; Dordick, J.S.; Linhardt, R.J. Interaction of Zika Virus Envelope Protein with Glycosaminoglycans. Biochemistry 2017, 56, 1151-1162. [CrossRef] [PubMed]

39. Albulescu, I.C.; Kovacikova, K.; Tas, A.; Snijder, E.J.; van Hemert, M.J. Suramin inhibits Zika virus replication by interfering with virus attachment and release of infectious particles. Antivir. Res. 2017, 143, 230-236. [CrossRef]

40. Behzadi, S.; Serpooshan, V.; Tao, W.; Hamaly, M.A.; Alkawareek, M.Y.; Dreaden, E.C.; Brown, D.; Alkilany, A.M.; Farokhzad, O.C.; Mahmoudi, M. Cellular uptake of nanoparticles: Journey inside the cell. Chem. Soc. Rev. 2017, 46, 4218-4244. [CrossRef]

41. Zhao, J.; Stenzel, M.H. Entry of nanoparticles into cells: The importance of nanoparticle properties. Polym. Chem. 2018, 9, 259-272. [CrossRef]

42. Unciti-Broceta, J.D.; Cortes, V.C.; Altea-Manzano, P.; Pernagallo, S.; Díaz-Mochón, J.J.; Sánchez-Martín, R.M. Number of Nanoparticles per Cell through a Spectrophotometric Method-A key parameter to Assess Nanoparticle-based Cellular Assays. Sci. Rep. 2015, 5, srep10091. [CrossRef]

43. Poon, W.; Zhang, Y.-N.; Ouyang, B.; Kingston, B.R.; Wu, J.L.Y.; Wilhelm, S.; Chan, W.C.W. Elimination Pathways of Nanoparticles. ACS Nano 2019, 13, 5785-5798. [CrossRef] [PubMed]

44. Chithrani, D.; Chan, W.C.W. Elucidating the Mechanism of Cellular Uptake and Removal of Protein-Coated Gold Nanoparticles of Different Sizes and Shapes. Nano Lett. 2007, 7, 1542-1550. [CrossRef] [PubMed] 